\title{
Teaching Literature in A Doll's House Drama
}

\author{
Izza Amalia Rahman \\ izzaakaizvi@gmail.com \\ Universitas Islam Malang \\ Mutmainnah Mustofa \\ inamustofa@unisma.ac.id \\ Universitas Islam Malang \\ Irfan Susiyana Putra \\ irfansinkrom@gmail.com \\ Universitas Islam Malang
}

\author{
Abdul Moueed \\ drmoueeduaf@gmail.com \\ University of Agriculture Faisalabad
}

\begin{abstract}
In education, teaching literature is an essential way to strengthen students' character building. A kind of literature to teach character building is drama. Drama is literary work that contains so many characters. It can be used as a tool for character development to students who have been taught with literature. This article aims to discuss the characters of Nora Helmer (a woman lived in Victorian era when women had powerlessness) in A Doll's House Drama written by Henrik Ibsen. The method used is descriptive qualitative. It concentrated on providing explanation in the form of description about Nora Helmer's characters that could be taught as students' character building. The analysis of Nora's characters results several findings. Woman's figure represented by Nora's characters are loyal, love and compassion; obedient; care and helpful; patience and spirited; responsible; brave. The findings show that a woman at that time even though she had a lot of difficulties, she tried to solve the problem, she tried to be the best for her husband and family. But when she was disrespected, she had to be brave to uphold her dignity. This article expects the students can increase their good characters, competence, conscience, and compassion in learning language.
\end{abstract}

Keywords: A Doll's House Drama; Character Building

\section{INTRODUCTION}

Literature is one of important aspect for teaching and building character in ELT class. According to Mustofa (2018: 1), literature is a definition of personal and social aspects of human nature, as well as human awareness that is equal to the shape of life itself. Important literature explored as a way of exchanging 
experiences (sharing) in the quest for and exploration of humanity's reality. There is not a lot of literature about writing, but there is a lot about how language is used to convey ideas. The professionals argue that literature contains materials that appropriate to motivate students and increase their good characters. Kasim (2003:1) in his book, stated that, literature arose from creative minds of people with the ability to construct stories and perceive what was going on around them, from natural phenomena to the lives of their neighbors. There are many types of literary works, including drama, novel, short story, and also poetry (Mustofa, 2018).

However, in ELT class, not all students feel interest and they think that literature is something difficult to be studied because the unfamiliarity of the language used. In ELT the most common literary works for students such as pros (short stories, fable, legend, etc), novels, poetry (poem), or dramas are popular and familiar for them, so it can be used to develop teaching strategies and to increase students' interest in literature. In connecting literature with human experiences to build students' character, one of the most appropriate ways is teaching them with a drama and one of the most popular drama is about the roles of a woman in life.

The roles of a woman in life, especially for the family are crucial. A woman with a good character and affectionate personality is crucial in raising her children so that the family she coached becomes a harmonious family. In the social reality, Ruddick and Daniels (1977:9) in their book "Working it Out" stated that the woman is creating community, sharing work and discovering that in the sharing of work our relationship with each other, become larger and more serious. Aside from that, technological and political developments are contributing to an increasing number of women choosing to earn an independent living, pursue a profession, or grow their own jobs. In the life of women in society as an important part of life must be able to develop all the potential that exists. In addition, women also provide their roles in providing assistance to others in need in many areas that can improve life processes.

In this research, the writers chose a drama entitle A Doll's House. Henrik Ibsen (1828-1906) wrote A Doll's House, which is considered a classic in the history of European theater. The drama written in 1879 , contains the basic problems that every couple faces around the world. A Doll's House is a drama about a young housewife who is treated like a doll and goes through a tough family life. Despite the fact that the story portrays the life of a woman who is always treated like a woman and a doll, the main character "Nora Helmer" desires to fulfill her roles in order to live a better life.

This research focuses to find out the character of the main role "Nora Helmer", as the interpretation the roles of a woman in life. Is she appreciated by husband or people around her? Does she has suffering to live as woman? By analyzing A Doll's House drama, it will be found several characters of a person. It should make the students to think creatively about literature in ELT class. To put it another way, the aim of this article is to demonstrate the characteristics of "Nora Helmer" in the 
drama A Doll's House so that students can learn about character building in ELT class through literature.

\section{LITERATURE REVIEW}

\section{Previous Related Study}

There are three previous related study. The first one is conducted by Dewi (2019) about "Teaching Literature with Tough Topic in ELT class: Bullying and Bigotry". Research conducted by Dewi (2019) focused on two short stories entitle "All Summer in a Day" by Ray Bradbury and "Shame" by Dick Gregory. However, this research focuses on woman's characters in A Doll's House Drama written by Henrik Ibsen so there is two more previous related study from Rosita \& Indrawati (2015) about “Henrik Ibsen's A Doll's House: Woman's Figure Representation in the Victorian Era" and Silitonga (2019) entitle "The Roles as Woman in Henrik Ibsen's A Doll House".

\section{Synopsis of A Doll's House Drama}

Nora Helmer is the protagonist and plays the role of a puppet in Henrik Ibsen's drama A Doll's House. The drama takes place at a time when the stereotypical roles of a man and a woman in marriage were still in practice in the nineteenth century. The main point that Ibsen tried to uncover is "dolls cannot play everything they want". It means that the story relates with the condition of women's powerlessness. In order to achieve the ideal wife's figure, she is willing to obey her husband Torvalds Helmer submissively and calmly. Their family called successful in term of financial after years hard work. Although they are in a middle-class family, many people are facing economic problems, they are still strong and lead a happy life.

The story begins of happiness and harmoniously of a couple marriage Torvald Helmer and his cheerful wife Nora. Nora is a person who lives in an imaginary world. Now that her husband's salary has increased, she is very excited and believes that there will be no financial problems from now on. On the other hand, Torvald did not like her habits because he was thought to spend a lot of money, so Torvald called her a "thrifty" person. Even though Nora is a young woman and her life is full of positive imagination, deep down she still wants to be the person her husband wants her to be. Nora likes her atmosphere so much that she likes it and asks her to pick things for things she doesn't do-except Torvald.

When Nora used forgery to apply for her husband's medical expenses loan, evidence of her love appeared. It made Nora had to receive money for her husband. She forged her father's signature even though her father was died, because at that time women were not allowed to lend the money. Nora did that because she loved her husband and thought her husband would be proud of her. Furthermore, she did not realize the criminal act she has already done and it made her husband furious. They could not communicate each other well. They have never sat down together and 
have serious talk as a husband and wife. Even though Nora's sacrifice was so deep, all Torvald did when he knew about his wife, he only yelled and scolded her.

Knowing his wife did something bad for his reputation, Torvald was very mad and made Nora told about anything she felt at their last eight years of marriage. She did not want to be "a doll" anymore. Her father and her husband have both treated her in an unfair manner. When she lived with her father, he fed her all of his thoughts before she eventually agreed with him. If she didn't, she stayed quiet because she knew it would upset her father. Her father used to call her "his doll-child" and would play with her the same way she did with her dolls.

When she moved into Torvald's house, in fact, she became a "doll-wife". Torvald arranged everything according to his tastes and she adapted the same tastes. Perhaps, she just pretended to. She decided to live a beggar's live and made her living doing tricks for her husband. Then, Torvald learned that his wife was not an innocent doll. She already felt that she could no longer live in the doll's house that she believed to be her home for eight years. She always tried her best to satisfy her every wish and any request made by her husband. In the end, she also decided to leave her husband, which was undoubtedly a very difficult decision for her. Nora not only left her home and husband, but also the children she loved so much. In short, Nora has grown up and has been affected by the pain she has experienced so far. When everything she had now disappeared, everything fell apart. However, this actually makes Nora a strong and independent person. She was now seeking her own maturity, and at the same time, her actions finally make her a freer and more honest person in social life. In this sense, she has become the heroine of modern tragedies, and the drama of her life is modern tragedy.

\section{METHOD}

\section{Design and Samples}

The data for this research is presented in a form of words, clauses, phrases, and sentences. The method used is descriptive qualitative. The writers collected the data in several steps. First, the writers access youtube platform to watch $A$ Doll's House drama that had been produced by Elkins Production LTD in association with Freeward Films LTD in 1973. Then, the writers compared the drama with the written text by reading $A$ Doll's House translated by William Archer. Second, the writers transcribed the story and dialogs of Nora that show her characters for being a woman.

\section{Instrument and Procedure}

In this research, the writers used two instruments those are observation and documents to get the data. The writers conducted observation about characters of Nora Helmer in A Doll's House drama by watching the drama video on youtube and using observation checklist about the positive characteristics. After observing the video, then the writers used documents about the transcript text of $A$ Doll's 
House translated by William Archer. The writers have read the text and underlined the good characteristics of Nora Helmer.

\section{Data Analysis}

In analyzing the data, the writers use library research. According to Semi (1993:8), Library research means that the data will be taken from a written source. The writers use library research because the main data is taken from the text of the drama itself. Several books and e-resources are taken to support the research. The writers analyzed the data through several steps. Firstly, after transcribing the dialog of Nora, the writers identified her characters and personalities. Secondly, in order to teach literature for students' character building, so the writers chose the positive characters of the main role to be studied. The third is supporting the characters with the related theories for discussion. The last is making a result and a conclusion.

\section{RESULTS AND DISCUSSION}

By understanding the story of $A$ Doll's House, this research tries to discuss the characters of Nora Helmer, so that in English Language teaching class, the students can learn what is the good character they can get from her by understanding literature. According to research, there are numerous opportunities to teach character education in ELT while also developing students' linguistic and literary skills. This section will address some of the competencies and educational aspects of the characteristics found while taught with three pillars of Ignatian Pedagogy implemented in Jesuit education that can be achieved by students as stated by Dewi (2019: 69) such as competence, conscience, and compassion in mind.

According to Dewi (2019: 70) competence is characterized as the students' capability to analyze the intrinsic elements of short stories such as plot, setting, character, theme, point of view, figurative languages, symbol, etc, and to recognize literary devices. With a focus on character building, it can be expected that the students can learn several characteristics of Nora. Conscience refers to students' ability to increase their reading habits while also growing their imagination and innovation for their own enjoyment of learning. Compassion is a key aspect of reflective teaching that helps students cultivate the ability the ability to empathize other people. Students may manifest greater concerns, empathy, and reverence for others in their lives as a result of reading literature from around the world.

The use of literature in ELT should be oriented toward enhancing students' character for the quality of human life in order to achieve all of the above goals. There are several characters and personality that have been found from Nora's characters in A Doll's House drama such as: loyal, love and compassion; obedient; care and helpful; patience and spirited; responsible; brave. 


\section{Loyal, love, and compassion}

At that time, Nora was suffering a hard condition while her husband Torvald got a sickness. This family faced economic crisis. Nora lent money without her husband permission. Torvald stayed alive without knowing anything. Nora acted like a usual, showing her love and tried her best to her husband even though her husband treated her like his "doll". She did anything to show her love and compassion even though she had to act like a child and like a doll. In one act, Nora came from Christmas shopping and Torvald called her. Helmer asked from his room, "Is that my lark twittering there?". Then, Nora answered while opening parcels, "Yes, it is." Helmer continued to call his wife "Is it squirrel skipping about?", "When did the squirrel get home?". Nora just answered her husband without being mad because she was called like that.

Nora was treated like a child and called with some animal nicknames such as " $m y$ little lark", "the squirrel". In this drama, Torvald treated his wife as a child wife. However, Nora did not show that she uncomfortable or she was mad for being treated like that. From the dialog above, we know that she was only loyal to her husband.

\section{Obedient}

In another conversation, Torvald and Nora were talking about how to manage money because Torvald knew that Nora spent a lot of money to buy Christmas gifts. They had different opinion. However, Nora finally had to agree with her husband. Helmer was advising his wife "Nora! Nora! What a woman you are! But seriously, you know my ideas on these points. No debts! No credit! Home-life ceases to be free and beautiful as soon as it is founded on borrowing and debt. We two have held out bravely till now, and we won't give in at the last". At that time, Nora replied with showing her obedience, "Very well-as you like Torvald".

Another prove that Nora was obeying her husband is that when Helmer continued to advise her, "What are little people called that are always wasting money?". Without arguing her husband, Nora agreed what Torvald has been said, "Let us do as you suggest, Torvald, then I shall have time to think what I am most in want of. That is a very sensible plan, isn't it?", replied Nora.

Nora's obedience to Torvald revealed that she was reliant on him. Torvald was the one who had to be obeyed as the husband because he was the one who had gotten the money for their family. It made Nora was completely reliant to her husband.

\section{Care and helpful}

Nora is the representative of every strong and independent woman in the Victorian era, because she was portrayed as a loving and caring daughter, Mother and wife. She was a cheerful woman in front of others and has always liked her life, just like 
we saw at the beginning of Christmas. She was a woman who cares about her surroundings and sensitive to others. For example, when she gave a present to a maid at Christmas, it showed that she was a kind and caring person.

Another proves that she had cared and liked helping other people is that when her old friend Mrs. Linde came to her house. She called her Christina. Mrs. Linde was a widow and got live hard after divorcing her husband and she had left by her father. In that condition, Mrs. Linde needed a help. Nora told her with no doubt, "You mean Torvald could perhaps do something for you.", "And so he shall, Christina. Just you leave it all to me. I shall lead up to it beautifully, and think of something pleasant to put him in a good humor! Oh! I should so love to do something for you." (Ibsen, pg.17)

\section{Patience and spirited}

When Nora used forgery to apply for her husband's medical expenses loan, evidence of her love appeared. She was indeed a fake because she loved her husband so much. The life of Nora, who used to be like Doll's wife, is now a pragmatic woman who is willing to struggle day and night to repay the loan she borrowed. She used to work late into the night to make money. She was often tired, but sitting there to work and make money was still a pleasure. With a passionate passion, she said "Well, and besides that, I made money in other ways. Last winter I was so lucky. I got a heap of copying to do. I shut myself up every evening and wrote far on into the night. Oh, sometimes I was so tired. And yet it was splendid to work in that way and earn money. I almost felt if I was a man." (Ibsen, pg. 22)

\section{Responsible}

Nora was a caring mother and she felt it was her responsibility to teach her children how to behave. When Nora realized that she had done something wrong and violated the rules of society, she realized that to assassinate her was not a suitable mother. She believed that among Nora's many qualities and personalities, the most important aspect that a mother must possess was love, caring and always being loyal to her husband, even if she was full of financial problems. Besides, Nora's decision to receive a loan left her an obligation to pay that off. She had to pay the debt by herself because she knew that Torvald wouldn't give his approval upon borrowing and debt.

\section{Brave}

At the moment, Mr. Krogstad (a bank clerk, Torvald's employee) was coming and Nora was shock because she got the loan from him. She was afraid that Krogstad would bring up her issue of taking up the loan to her husband. After exiting Helmer's office, Krogstad asked Nora about Mrs. Linde that had an appointment in the bank. Even she was afraid how to deal with Mr. Krogstad, she tried to brave by 
showing off her power toward him by stating that although she was a woman, she had a huge influence on her husband.

And the end of the story, Nora was also brave for saying her husband that she did not want to be a doll and lived in a doll's house anymore. In the middle of their bickering, Torvald tried to hold Nora, "No stay. What are going to do?". Nora answered angrily, "To take off my doll's dress" (Ibsen, pg. 111). "We have been married eight years. Does it not strike you that this is the first time we two, you and I, man and wife, have talked together seriously?". Feeling confused and scared Torvald asked for clarity, "Seriously! Well, what do you call seriously?". Nora continued to talk with tears, "During eight whole years and more-ever since the day we first met, we have never exchanged one serious word about serious things." (Ibsen, pg. 113)

From the dialogs above, we know that Nora tried to be brave in front of her husband. Because of that situation, Nora decided to leave home, "I am going at once. Christina will take me in for tonight." Helmer still tried to hold her, "You are mad. I shall not allow it. I forbid it." Fearlessly, Nora refused her husband, "It's no use your forbidding me anything now. I shall take with me what belongs to me. From you I will accept nothing, either now or afterwards." (Ibsen, pg.116)

In this research, the writers found several positive characters of Nora Helmer. Those characters are loyal, love and compassion; obedient; care and helpful; patience and spirited; responsible; and brave. The characters of Nora Helmer represented the woman's role in the Victorian Era. She had to be everything her husband wanted to. She had to be perfect in front of her children. However, she decided to be brave because she felt suffering if she treated like a doll.

The discussion in this research shows the characters of Nora accompanied by evidence in the form of dialogs from the text drama. It also suitable with the previous study written by Silitonga (2019). Silitonga (2019) found several roles of woman and it showed the characters of Nora Helmer. He explained the Nora's roles as wife. Here, she represented characteristics of love, compassion, and care. Then, Nora's roles to provide a comfort for her husband. She showed a character that was obedient. Nora also gave support to her husband. She was patience and spirited. She was also care and looked for solution to her friend, Mrs. Linde.

The last characteristics of Nora is related with the second previous study written by Rosita \& Indrawati (2015). The last character is brave. Woman's figure represented by Nora Helmer was symbolized as "a doll". She acted childish and obedience. Because of that, she had a suffering being treated like a doll. In the last part of the drama, Nora decided to be brave and went away from home to get her freedom. 


\section{CONCLUSION}

Based on the findings, the writers purpose several conclusions in term of teaching literature through $A$ Doll's House drama. There are several characters of Nora Helmer as the focus discussion in this research. Those characters will be used as a character building for the students. It means that the students can get positive characters from another person so that in teaching literature, teachers give a lot of impacts for the students. First conclusion is about Nora's characters. As a Victorian woman who lived in a woman powerlessness era, Nora had several positive characters that can influence students' character building, such as loyal, love and compassion.; obedient; care and helpful; patience and spirited; responsible; brave. By understanding characteristics of a person through literature, so that the students have to be able to take the moral value and also get a lot of meaningful things from these. Second, teaching literature in A Doll's House drama, here the writers expect that the students can fulfill several competencies based on Ignatian Pedagogy applied in Jesuit education, that can be achieved by the students such as Competence, Conscience, and Compassion in mind. From this research, the writers suggest for the readers and for the next researchers who will conduct research in the same topic. First, the readers and future researchers can explain more detail about what did Nora Helmer feel, and what suffering did she feel. It will be more touching while teaching students about literature through a drama so they can be more empathic. Second, the future researchers can analyze deeper about what are the competences the students are expected to mater after learning literature in ELT class.

\section{REFFERENCES}

Dewi, N. (2019). Teaching Literature with Tough Topic in ELT Class: Bullying and Bigotry. LLT Journal: A Journal on Language and Language Teaching, 22(1), 66-77. Retrieved from https://e-journal.usd.ac.id/index.php/LLT

Gunawan, Y. B. (2014). English learning that fosters positive attitudes. LLT Journal: A Journal on Language and Language Teaching, 17(1), 35-41. Retrieved from http://ejournal.usd.ac.id/index.php/LLT/article/view/276/235.

https://en.wikipedia.org/wiki/Henrik_Ibsen

https://www.biography.com/people/henrikibsen-37014

https://etheses.uin-malang.ac.id

https://www.lib.unnes.ac.id

https://www.youtube.com/watch?v=XZo6gL3CwrE 
Ibsen, Henrik. A Doll's House: Translated by William Archer. T. Fisher Unwin. London.https://www2.hf.uio.no/polyglotta/public/media/libraries/file/10/A \%20Dolls\%20House-\%20Henrik\%20Ibsen.pdf

Ilyas, H. P. (2016). Retaining literature in the Indonesian ELT curriculum. Studies in English Language and Education, 3(1), 1-11.

Kasim, R. (2003). Introduction to Literature. Medan: USU Press.

Mariani, N. (2016). Developing students' intelligent character through linguistic politeness: the case of English as a foreign language for Indonesian students. English Language Teaching, 9(1), 101-106

Mustofa, M. (2018). Character Building Through Poem. Surabaya: Pondok Pesantren Jagad 'Alimussirry (Anggota IKAPI).

Rosita, F., \& Indrawati. (2015). Henrik Ibsen's A Doll's House: Woman's Figure Representation in the Victorian Era. Rainbow: Journal of Literature, Linguistics and Cultural Studies, 4(1), 44-57. Retrieved from http://journal.unnes.ac.id/sju/index.php/rainbow.

Ruddick, S., \& Pamela. D. (1977). Working It Out. New York: Pantheon Books.

Semi, Aftar M. (1993). Metode Penelitian Sastra. Bandung: Angkasa.

Silitonga, Andi Jaihutan. (2019). The Roles as Woman in Henrik Ibsen's A Doll House. Jurnal Littera: Fakultas Sastra Darma Agung, 1(1), 111-131. 